\title{
Destination Branding as a Strategy to Increase Positive Image of Indonesia
}

\author{
Carly Stiana Scheffer-Sumampouw \\ Universitas Pelita Harapan \\ Banten, Indonesia \\ carly.scheffer@uph.edu
}

\begin{abstract}
The effort to increase the image of Indonesia as a country, both internally and externally, has been a continuous homework. In Public Relations, the subject is called PR program or PR campaign. Whilst, President Jokowi's administration has formulated "Nawa Cita" in leading this country, the Ministry of Tourism has formulated a campaign "Wonderful Indonesia" or "Pesona Indonesia" since January $1^{\text {st }}$, 2011. This article highlights destination branding as a concept and use Pengabdian kepada Masyarakat (PkM) as the application of the concept. This PkM project will have been running since August until December 2016. The output of this $P \mathrm{kM}$ will be in a form of communication campaign which will promote one or more designated touristic pace in Indonesia. This campaign aims at mainly domestic audience or local tourists. The output of this project is a 30 minute audio-visual program which broadcasts about a particular destination in Indonesia, TVC from sponsor(s) and Public Service Announcement (PSA). This program will be spread through social media. There are mainly two targets of this campaign; first, the main target is the audience of social media. The community which was profiled by this program will be our second main target of this PkM project. This writing is about PkM proposal as well as the progress of the communication campaign.
\end{abstract} PkM

Keywords - branding, capstone, destination, image, Indonesia,

\section{INTRODUCTION}

Indonesia has reached its independence for 71 years now. A lot of people are celebrating this Independence Day, a lot of communities are commemorating it. The most certain activity is the flag ceremony, yet different communities have their own ways and activities in celebrating August $17^{\text {th }}$. In relation to that, the writer as part of team teaching of Capstone subject in Communication Science FISIP UPH, would like to contribute in commemorating Independence Day by excelling a community service activity (Pengabdian kepada Masyarakat/PkM). The community service will be internalized in capstone subject ( 3 credits). One batch of communication students of all 3 concentrations (PR/IMC/Journalism) will form a team and conduct communication campaign in which those campaigns will help to solve social problems in our countryIndonesia.

Capstone subject in our curriculum is a culminating subject where the analogy is like a student writing their final thesis or internship report. The difference is that this class is done as group project. A team work component is extremely important in capstone, because one person cannot tackle the social problem alone. Quoting basic principles of capstone subject compiled by Australian government: (htt)

In short, great capstones involve: integration and extension of prior learning, authentic and contextualized experiences, challenging and complex scenarios, student independence and agency, a concern with critical inquiry and creativity, active dissemination and celebration.

Listening to a distinguished guest speaker's speech on the $23^{\text {rd }}$ UPH Festival -TNI General Mr.Gatot Nurmantyo- where he quoted that based on discussion of 25 universities all over Indonesia, Lemhannas RI and TNI educational institutions, there are at least 16 points or foreign strategies presumably are aimed to Indonesia-known as "proxy war". Proxy war is a confrontation between two great powers, using 'stuntmen' in order to avoid direct confrontation to lessen the risks of direct confrontation, resulting fatal destruction. (Nurmantyo, 2016)

Destroying the image of Indonesia internationally with the issues of terrorism, human right violation, democratization, environment, and et cetera, displaying Indonesia as a market of narcotics and illegal drugs as well as destroying our young generation through drugs and narcotics, creating euphoria that students leaving campus; neglect studying, party addicts, demonstrations and fights (Nurmantyo, 2016), aren't these conditions are happening right now within our society?

Freedom from colonialism is already earned, but our fight is not yet over, especially in combating the above issues. From communication point of view, how do we use our knowledge and skill in increasing positive image of Indonesia internally as well as externally? Coming from this thinking, the writer as communication lecturer in UPH, has formulated a community service project to promote good image of Indonesia in the eyes of Indonesians, through destination branding.

"Indonesia Bagus", "My Trip My Adventures", "Ring of Fire Adventures" and "Weekend List" are only few titles about travelling which dominates our national television stations. Two of them -in fact- are supported by tourism ministry of Indonesia through their campaign "Pesona Indonesia". (htt1) One might wonder why the English titles are favorited by Indonesian producers. This writing is a proposal of a community service (abbreviated as $\mathrm{PkM}$ ) of academicians; lecturers, laboratorial staffs and the communication students of Universitas Pelita Harapan batch 2014. 


\section{A. Communication Science Contribution to Society}

Looking at the $4 \mathrm{TV}$ titles above, the writer comes up with an idea to initiate several activities which have several objectives. The first activity is a community service program, because within this project merge together the theories taught in class with the skills and creativity of communication students in answering social problems in our society. The writer has chosen "Nationalism" as a theme and "Destination Branding" as a sub-theme for this PkM. The idea project is to promote designated touristic place in order to increase nationalism among Indonesians. Thus, the problem underlies this theme is how a destination branding strategy can increase the image of Indonesia among Indonesians.

The writer named this activity as "A Nationalism Project". The goal for this campaign is for the videos can increase the pride being Indonesians in the selves of students, touristic designated community, and to all viewers upon realizing the beauty of Indonesia's nature. This pride strengthen nationalism. While several objectives of this campaign are; (1) to facilitate students in applying skills and knowledge after 2year of studying, (2) to promote places in Indonesia as touristic destinations. By promoting the nature, the richness of culture and the society creative economy, the communication study program will then help certain community to become touristic destination, (3) to present an audio-visual program that is informative and yet entertaining, (4) these videos will be disseminated through social media only and hope to elevate the image of Indonesia as a country.

\section{B. An Audio-Visual Campaign that Supports Government}

Effort to increase image of Indonesia, internally as well as externally, has been a continuous effort. In communication science, this is the study of public relations (PR) that implied on the subjects of PR program or PR campaign. Anne Gregory spoke about PR campaign as follows:

To plan and manage programmes (long term, planned activities aimed at addressing difficult and/ or complex issues and opportunities that require an ongoing approach) and campaigns (shorter term, planned activities aimed at addressing a specific and time-limited issue or opportunity) effectively it is vitally important to look at the context in which public relations activity takes place, since this differs from organization to organization. (Gregory, 2014)

Therefore, PR campaign tends to be used on a shorter length of time, while PR program is the term for the long term strategy. The core of this capstone project is campaign. The campaign aims at elevating nationalism towards the citizen. In other words, the community service is excelling a PR campaign, using audio-visual program, disseminated through social media in order to support government of Indonesia. UPH communication science has 3 concentrations: Broadcast Journalism, Integrated Marketing Communication and Public Relations. One definition of PR

$P R$ is a discipline that looks after reputation, with the aim of earning understanding and support and influencing behavior. It is the planned and sustained effort to establish and maintain goodwill \& mutual understanding between an organization and its publics. (htt2)
PR is a discipline that is paying attention to reputation. Reputation in this case, can be an individual (for example a public figure), organization reputation nor a country reputation. Preserving reputation and earning the same understanding between organization and its publics are PR's job. The publics consists of 2 ; internal and external. But, the definition of publics according to Gregory can be enlightening:

The word 'audience' is sometimes used in public relations. Audiences are usually broad, undifferentiated groups, reflecting the fact that the word originates from the world of the mass media. Hence, TV and radio have audiences, and these not only comprise large numbers, but also include isolated individuals who are not organized into recognized groups. Finally, 'target groups' is a term sometimes used in public relations. These are the groups at which the campaign or programme is aimed: it is their attitudes and behaviours that the originator of the communication wishes to affect in some way. (Gregory, 2014)

Jokowi's presidential has formulated "Nawa Cita" in leading this country and the ministry of tourism has planned a PR program called "Wonderful Indonesia" or "Pesona Indonesia" since 1 Januari 2011 (in the past this program is called "Visit Indonesia"). (Drs. Putu Ngurah, 2016)

UPH communication study program, specifically the faculty and the students of capstone subject have decided the target group of this campaign is all Indonesian people, numerous in ages but must be connected with internet and light social media users. However, our target audience for this matter is male and female, above 17 years old (the same age as lecturers and students), domiciled in Indonesia, exhibit travelling and adventurous lifestyles and spend at least 1 hour a day in social media. Approximately by October to November, there will be 4 audio-visuals, duration 30 minutes, promoting touristic places in Indonesia, presenting the beauty of nature, highlighting the richness of culture and profiling the story of individuals as part of designated community. The video is the main part of the campaign. A campaign through social media. A campaign that supports government, in this case Indonesia ministry of tourism, by prioritizing 4 out of 10 top destinations in Indonesia; (htt3) promoting Indonesia to Indonesians.

\section{THE OUTPUT}

The output of this activity, as mentioned in the introduction, UPH communication study program will create videos of a total 30 minutes. The actual content duration ranges between $22-24$ minutes, while break time is 6 to 8 minutes. The video will be constituted of 3 segments with 2 break times, similar to national TV channels. This video is a collaboration project among lecturer, students and laboratorium staffs FISIP UPH. Program segment (22-24 minute-length) are visualizing journalistic approach in covering touristic destination. While the break times will consist of TVC (TV commercial), PSA (Public Service Announcement) and the promo ON AIR of the program itself. After the editing process, will then this program be uploaded on social media. Each group member has at least one social media vehicle. Social media vehicles are for example: facebook, twitter, youtube, instagram dan whatsapp atau line. 


\section{BRANDING STRATEGY}

\section{Branding Model}

If translated into Bahasa, branding is called "merk". But, the writer keeps the term "branding" in this article. In his book Principles of Internet Marketing: New Tools and Methods for Web Developer, Jason Miletsky proposes a successful branding model that is quite simple, understandable and applicable. There are 4 elements which enables a brand to reach success, as described below:

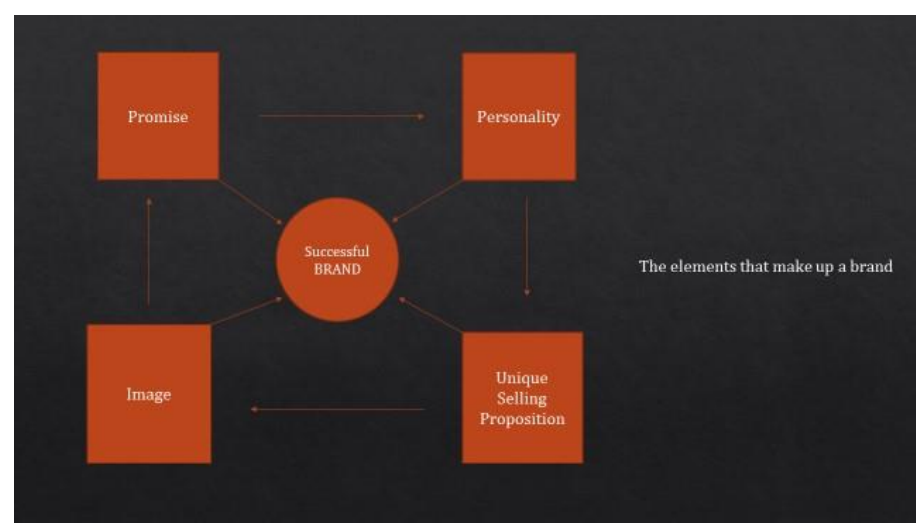

Fig. 1. Model branding according Jason Miletsky (Miletsky, 2010)

To become a successful brand, each must defines a "brand promise", "brand personality", "USP" and "brand image". A simple definition of brand promise is the promise from producer to consumer; brand personality means the identity the brand owns, for example brand "Apple" owns personality of "innovation, individualism and imagination"; then Miletsky defines brand image as a visual form or the image presented to the consumers in the form of logo, symbol, color, packaging, character such as "Ronald McDonald" and "Colonel Sanders in KFC".

\section{Unique Destination Proposition}

Second edition of textbook by Morgan, Pritchard and Pride titled "Destination Branding" offers a different terminology from other branding books, that is unique destination proposition (Nigel Morgan, 2004). This proposition has actually the same meaning with unique selling proposition (USP). Tourism in each country eagerly wants to showcase culture richness, history and the beauty of its nature. However, we might argue that each country or each destination also have that feature. Therefore, a unique destination proposition argues that each destination has something that is truly unique that other destination does not have. For example Rome in this case Vatican -has a nickname The Eternal City. And then there is Paris which has closely associated by the word "romantic". Bali is internationally well-known as "The Islands of gods".

\section{Country Branding}

In many cases, the name of a country attached to a product will help a consumer decision to buy. We are familiar with the term "Made in...". Take one example our country-Indonesia when is compared by "Bali", Bali is more famous as touristic destination internationally. In this case, we can say that Bali's equity leverages Indonesia's equity. The image of a country has an impact to consumer's decision on buying, investment even in choosing a touristic destination. The image of a country defined by Kotler (Go, 2009)

The sum of beliefs and impressions people hold about place. Images represent a simplification of a large number associations and pieces of information connected with a place. They are product of the mind trying to process and pick out essential information from huge amounts of data about a place. (Kotler et al, 1993: p.42)

Similar to country branding, nation branding is defined as (Go, 2009)

"... how countries can position themselves in the global marketplace in order to boost exports, inward investment, tourism and much more besides, ...." (Anholt, 2004, p.28).

If that is the case then, place or destination branding is part of country or nation branding. Both propositions have a mutualism symbiosis; which means that a well-known destination will attract visitors and adds on foreign exchange, on the contrary a good image of a country will invite more visitors to come to that country.

\section{Destination branding}

The concept of destination branding is derived from strategic brand management which was popular in 1980s. The essence however, destination branding is a strategy to promote touristic destination and with the same concept as branding in general, that is to win competition. These days, a destination competes one another to reach their target of tourists.

These definitions are leading to the practice of $\mathrm{PkM}$ in UPH communication study program. Destination branding or place branding concept is (Dewi, 2009)

The marketing activities (1) that support the creation of a name, symbol, logo, word mark or other graphic that both identifies and differentiates a destination; (2) that convey the promise of a memorable travel experience that is uniquely associated with the destination; and (3) that serve to consolidate and reinforce the recollection of pleasurable memories of the destination experience, all with the intent purpose of creating an image that influences consumers' decisions to visit the destination in question, as opposed to an alternate one. (Blain et al,2005: p.331-2)

Golf and Ward (1994, p.2) mentioned (as quoted in Go, 2009) that numerous ways are to activate destination branding, they are advertising, direct marketing, personal selling, websites, brochures, PR and media relations even cooperation between Destination Marketing Organizations (DMOs) as well as film makers. Film making can have an impact to place branding, for example the Indonesian films that attracted touristic visitors after their broadcasts, for example "Laskar Pelangi" which popularized Belitung island and "Gereja Ayam" in Jogjakarta which is famous thanks to the movie AADC 2. (htt4)

... not only involves advertising and publicity, but also encompasses 'flagship' developments and 'spotlight' events in the arts, media, leisure, heritage, retailing or sports industries (Ward, 1994). 
In other words, communication study program with a campaign "A Nationalism Project" creates an opportunity to apply knowledge through a community service based on certain concepts: country branding has a mutualism symbiosis with destination branding, while the tools for destination branding is using marketing communication and public relations as well as journalistic program -a video of 3 segments, 30-minute length. This video program will be disseminated 2 ways; digital campaign, where these audiovisuals will be uploaded through social media. And the continued step is offline campaign, where the students of communication will conduct a movie screening in campus within the month of November 2016. The month of December will be the end period of campaign and the period of final semester for capstone subject.

\section{METHODS}

\section{A. Stages of Production}

The stages in producing video are 3: pre-production, production and post-production. In pra-production stage, a holistic theme campaign is decide by leacturers teaching theme, while the sub-theme campaign is decided by lecturer. And these themes will be articulated in a program title or episodic title by the communication students. Students themselves will decide the title for this 30 -minute program and submit the title in a proposal of 6 chapters (the sample of proposal is attached). This project will be produced by a group of 12 to 13 students.

The production stage will happen after the approval of the proposal by lecturer. Shooting process will take place 3 to 5 days in a particular place written in an approved proposal. As explained by the previous chapters, we will take journalistic approach (we will produce something like "Indonesia Bagus" as opposed to "Laskar Pelangi"). This semester, we decide to prioritize 4 touristic places, they are: Kepulauan Seribu, Tanjung Lesung, Yogyakarta dan Banten lama (sample video is attached).

The last stage consists of editing process, selecting the good quality of pictures, inserting sounds or voices, put back sound, written texts or even photos and all the student's coverage. This stage is called post-production. Post production is crucial because this is also the moment for communication study program conduct a digital campaign -promoting their videos about destinations only and mainly to social media. On the other hand, offline campaign will take place in movie screenings which will be held in 4 different days in November.

\section{B. Human Resources}

Human resources being involved in this $\mathrm{PkM}$ project consists of lecturer team (3 persons), 144 communication students (but only 50 students involved in destination branding campaign), laboratorial staffs ( 2 persons). Each individual roles will be listed on credit title of the video as the attached example.

\section{Budgeting}

Budget plan to execute this activity is maximum Rp.6.000.000,- for each group. Should there be any additional fee in order to excel this program, the group should then initiate to look for sponsorships (finding sponsorship is actually the application of subjects Intro to IMC and Business Law, sample of the MoU is attached). The budget amount has been calculated based on that UPH campus has provided video camera facility, studio room, editing and uploading facilities for students and lecturers who need it.

\section{RESULTS}

As written on picture 1 chapter 1 , this activity is derived due to a frame of thinking to conduct "tridarma" higher education in one homogenous theme project. The universities should produce a work resulting from academics thinking and that work is useful for not only academia community, but also to communication industry as well as public in general. In a PkM "destination branding", capstone subject offers an opportunity for students to apply their knowledge and skills in communication science.

These are list of subjects that minor parts of the subjects are applied in this capstone, such as: PR Campaign, Public Speaking, Desktop Publishing, Multimedia, Intro to IMC, Marcom Management, Intro to Advertising, Business Law, Strategic Brand Management, Intro to Journalism, Radio \& TV Journalism, TV Production, TV Commercial Production, Internet Marketing \& Cyber PR. By social media penetration, this program serves 2 target groups, the first audience is those who watch this program through social media, while the second one is the community in which their place has been promoted to be a touristic area. Based on this understanding, the benefits are various; university students can practice their creativity in producing audio-visuals, the audience receive an informative yet entertaining program and the whole PkM project will elevate the positive image of Indonesia, especially the internal public -the Indonesians.

Destination branding as part of country branding has an initial purpose to strengthening the love of country. People realize that this country has a lot to offer and its destinations are magnificent compare to other countries. This awareness will create touristic experience. Values proposition of this touristic experience are FUN, INDIGENOUS and NUSANTARA. These values are visualized in 3 segments program which is called PESONA INDONESIA. FUN means that this program has to entertain its audience which is visualized by all the touristic attraction that the place has. INDIGENOUS means that this program has to highlight the native community within that place, their culture, economiccreative and how the community spend their leisure time. The last value is NUSANTARA which means besides documenting the beauty of the nature, students will interview local or central government on the issue of tourist destination. The logo and campaign title are chosen PESONA INDONESIA is the same with government's initiative. The reason for the same name, logo and jingle is because we need to maintain consistency the brand which already exist in the market. Consistency is one criteria for brand management. (Keller, 2013) Second reason is 
that this UPH community service is supporting the program of the government of Republik Indonesia, specifically tourism ministry of Indonesia.

\section{CONCLUSION}

After executing both campaign online and offline, the writer will continue to follow up with a research discussing the effectivity communication campaign on strengthening the nationalism on the people of Indonesia. Research question would be: after watching the campaign PESONA INDONESIA on social media, do people want to visit that place? Whether or which social media is the most effective in reaching audience? Are these videos have reflected the values: fun, indigenous and nusantara? And finally, is the program campaign of PESONA INDONESIA strengthening the audience nationalism?

As a closing and suggestion to our government (specifically ministry of tourism RI), the writer encourages for the subject "Capstone" UPH to be adopted by other universities, especially those which has communication study program. If this curriculum of capstone is adopted then there will be more touristic places in Indonesia can be promoted. Kemenpar RI has already collaborated with media companies, however it is deemed crucial for Kemenpar to collaborate with higher education institutions in order to create a sustainable destination branding policy. Information dissemination through social media has a wider reach and also durable compare to television program which ended when the show time is over.

\section{REFERENCE}

(t.thn.).http://www.capstonecurriculum.com.au/the-capstoneprinciples/)

(t.thn.). http://www.indonesia.travel/landing

(t.thn.). https://www.cipr.co.uk/ (t.thn.).http://travel.detik.com/read/2016/10/21/142058/33263 41/1382/mengenalkan-10-bali-baru-di-singapura

(t.thn.).http://blog.dwidayatour.co.id/blogpage/inilah--tempatyang-berubah-menjadi-destinasi-wisata-karena-sebuahfilm

Dewi, I. J. (2009). Creating and Sustaining Brand Equity: Aspek Manajerial dan Akademis dari Branding.

Direktorat Riset dan Pengabdian kepada Masyarakat, Direktorat Jendral Penguatan Riset dan Pengembangan, Kementrian Riset, Teknologi dan Pendidikan Tinggi. (2016). Panduan Pelaksanaan Penelitian dan Pengabdian kepada Masyarakat di Perguruan Tinggi Edisi X.

Drs. Putu Ngurah, M. (2016, June). Asisten Deputi Pengembangan Komunikasi Pemasaran Kementrian Pariwisata RI. (Z. team, Pewawancara)

Go, R. G. (2009). Place Branding: Glocal, Virtual and Physical Identities, Constructed, Imagined and Experienced. Palgrave Macmillan.

Gregory, A. (2014). Planning and Managing Public Relations Campaigns: A Strategic Approach (PR in Practice).

Keller, K. L. (2013). Strategic Brand Management: Global Edition. Pearson.

Miletsky, J. (2010). Principles of Internet Marketing: New Tools and Methods for Web Developer.

Nigel Morgan, A. P. (2004). Destination Branding, Second Edition: Creating the unique destination proposition. Butterworth-Heinemann; 2 edition (August 12, 2004) .

Nurmantyo, G. (2016, Agustus 19). Memahami Ancaman, Menyadari Jati Diri Sebagai Modal Membangun Menuju Indonesia Emas. Pidato pada UPH Festival. Karawaci, Tangerang, Banten: Universitas Pelita Harapan. 